\title{
Isolation, Characterization and Screening of Azospirillum from Tuberose Rhizoplane in Raichur
}

\author{
M. Avinash* and Mahadeva Swamy \\ Department of Agricultural Microbiology, University of Agricultural sciences, \\ Raichur-584104, Karnataka, India \\ *Corresponding author
}

\section{A B S T R A C T}

\section{Keywords \\ Azospirillum, Acid production, Biotin requirement, \\ Denitrification, IAA, Nitrogen fixation \\ Article Info \\ Accepted: \\ 07 October 2018 \\ Available Online: \\ 10 November 2018}

An experiment was carried out to isolate, characterize and screening of Azospirillum from tuberose rhizoplane. 40 bacterial strains were isolated showing characteristics of Azospirillum. Isolates were characterized based on utilization of glucose, biotin requirement, acid production in glucose peptone broth and denitrification test. Out of 40 isolates, 20 isolates required biotin for their growth and remaining 20 showed growth without biotin. 16 isolates showed positive for denitrification and they were tentatively identified as Azospirillum brasilense. All isolates produced acid and utilized glucose as carbon source. Isolates showed negative for denitrification test were screened through In vitro analysis.

\section{Introduction}

Azospirillum, a ubiquitous rhizosphere bacterium, representing the main group of microaerophilic free living/associative nitrogen fixing bacteria (Dobereiner and Day, 1976). They are isolated from the rhizosphere of many grasses and cereals all over world and their roles on plant growth and yield have been well established (Wani, 1990; James, 2000). Two species viz., Azospirillum brasilense and Azosprillium lipoferum have been found in soil of a temperate zone (Coninck et al., 1988) and even in the cold climate of Finland (Haathella et al., 1983). According to Reynders and Vlassak (1979)
Azospirillum occurs in about $90 \%$ of tropical soil and in about $60 \%$ of soils in the temperate zone. A. brasilense is attributed to have affinity with plants with photosynthesis type C3 (wheat and chilli), whereas A. lipoferum with plants of $\mathrm{C} 4$ type (Maize and Sorghum). $\mathrm{N}_{2}$ fixation may be one of the minor mechanisms involved in plant growth promotion by Azospirillum (Michiels et al., 1989; Bashan and Levanony, 1990). The success of Azospirillum inoculants in promoting plant growth will largely depend on its movement towards the host plant both in black soil and red soil in the rhizosphere (Bashan et al., 1987 and Bashan and Holguin, 1994). The stimulatory effect exerted by 
Azospirillum has been attributed to several mechanisms including secretion of phytohormones, biological nitrogen fixation, and enhancement of mineral uptake by plants (Okon and Itzigsohn, 1995; James, 2000).

\section{Materials and Methods}

\section{Isolation of Azospirillum}

The standard isolation procedure, as reported by Dobereiner and Day (1976), was followed for isolation of Azospirillum from tuberose root samples. Fresh root samples were cut into bits of $0.5 \mathrm{~cm}$ length and then were washed thoroughly in running tap water and surface sterilized by dipping in $0.1 \% \mathrm{HgCl}_{2}$ solution for three minutes followed by dipping in 70 per cent alcohol for one minute. The roots were finally washed in six to eight changes of distilled water. The root bits were then placed at subsurface level in screw cap tubes containing sterilized Nitrogen-free semi solid malate medium (Okon et al., 1977) under aseptic conditions.

The tubes were incubated at $37^{\circ} \mathrm{C}$ for a period of 4-5 days and observed for growth of Azospirillum as subsurface white undulating pellicles. The isolates were purified by repeated sub culturing. A loopful of culture was streaked on malate agar plates containing 1 per cent $\mathrm{NH}_{4} \mathrm{Cl}$. After a week of incubation, typical small, white dense single colonies were picked and transferred to semisolid $\mathrm{N}$ free malate medium in culture tubes. The isolates that formed characteristic subsurface white undulating pellicle in this medium were tentatively considered as Azospirillum.

\section{Biochemical characterization}

The biochemical tests viz., utilization of glucose, biotin requirement, acid production in glucose peptone broth and denitrification tests were carried out for identification of the
Azospirillum isolates. The isolates of Azospirillum were grown in nitrogen free malate medium $(\mathrm{nfb})$ for $48 \mathrm{hrs}$ at $28^{\circ} \mathrm{C}( \pm 2)$ over an environmental shaker (100 rpm).

\section{Utilization of glucose}

Five $\mathrm{ml}$ of semi-solid nitrogen free glucose broth was dispensed into test tubes and autoclaved at $15 \mathrm{lbs}$ for 20 minutes. These test tubes were inoculated with $0.1 \mathrm{ml}$ of the standard inoculum of Azospirillum isolates. The tubes were incubated at $28^{\circ} \mathrm{C}( \pm 2)$ for 3 days. Observations were recorded for the appearance of turbidity in the test tubes as indicated by the utilization of glucose.

\section{Biotin requirement test}

Two sets of test tubes containing $10 \mathrm{ml}$ of nitrogen free semi-solid medium were prepared, one with biotin $(100 \mathrm{mg} / \mathrm{L})$ and another without biotin. The test tubes were sterilized at $121^{\circ} \mathrm{C}$ for 30 minutes and cooled to room temperature. These test tubes were inoculated with $0.1 \mathrm{ml}$ of the standard inoculum of Azospirillum isolates. The tubes were incubated at $28^{\circ} \mathrm{C}( \pm 2)$ for 3 days. After three days of incubation, growth of Azospirillum isolates was observed in the tubes. In case where growth occurred in the medium without biotin, a second transfer was made to fresh medium without biotin and biotin requirement was confirmed.

\section{Acid production in glucose peptone broth}

Five $\mathrm{ml}$ of glucose peptone broth with Bromothymol Blue (BTB) was dispensed into test tubes and autoclaved at $121^{\circ} \mathrm{C}(15 \mathrm{lbs})$ for 20 minutes. Overnight cultures of Azospirillum isolates were inoculated $(0.1 \mathrm{ml})$ into the test tubes. The tubes were incubated at $37^{\circ} \mathrm{C}$ for three days. Colour change in BTB from green to yellow indicated acid production. 


\section{Denitrification test}

Nitrogen free solid malate medium supplemented with $5 \mathrm{M}$ ammonium nitrate was prepared. The medium was dispensed in $5 \mathrm{ml}$ quantities in test tubes and sterilized at $121^{\circ} \mathrm{C}$ (15lbs) for 30 minutes. The test tubes containing the medium was stab inoculated with the stock culture of Azospirillum isolates. The tubes were incubated at $28^{\circ} \mathrm{C}( \pm 2)$ for three days. The tubes were observed for shredded agar block. Shredded agar block indicated that Azospirillum isolates were positive for denitrification test.

\section{Results and Discussion}

A total of forty isolates have been isolated from root bits of Tuberose grown in herbal garden, AC Raichur and tentatively confirmed as Azospirillum based on cell morphology i.e., spiral and twisted shape, characteristic rotating corkscrew type of motility, white dense colony morphology and formation of white pellicle in the subsurface of nitrogen free semisolid malate medium. Based on biotin requirement, of the total forty isolates characterized 20 isolates were found to be $A$. brasilense while remaining 20 isolates were unidentified. Total forty isolates characterized were coded serially from ATR-1 to ATR-40. Almost all isolates produced acid in glucose peptone broth and utilized glucose in the medium as a source of carbon (Table 1).

In vitro screening of Azospirillum isolates from root bits of Tuberose (Table 2)

\section{In vitro $\mathrm{N}_{2}$ fixation}

Di-Nitrogen fixation is naturally the first major mechanism of action suggested for the enhancement of plant growth by Azospirillum. Total nitrogen fixation ranged from $12.7 \mathrm{mg}$ of N/ g to $16.6 \mathrm{mg}$ of N/g of malate utilized. Significantly highest nitrogen fixation was observed in the isolate ATR-06 (16.6 mg of $\mathrm{N} / \mathrm{g}$ of malate). Significant higher $\mathrm{N}_{2}$ production by ATR-06 may be due to well adoption to the surrounding environment and efficient utilization of nutrients present in the medium. Reports of nitrogen fixing efficiency of Azospirillum isolates isolated from grasses ranged from $3.4 \mathrm{mg}$ to as high as $61.12 \mathrm{mg}$ of nitrogen fixed per gram of carbon source consumed (Santosh swamy, 2006). Savalgi et al., (2009) examined the in vitro $\mathrm{N}_{2}$ - fixation efficiency of Azospirillum isolates on $\mathrm{N}$-free semi-solid malate medium and reported that $\mathrm{N}_{2}$ - fixed in the semi-solid medium ranged from 1.4 to $20.96 \mathrm{~N} \mathrm{mg} \mathrm{/g} \mathrm{of} \mathrm{malate.}$ Kanimozhi and Panneerselvam (2010) reported the maximum nitrogen fixation of $15.6 \mathrm{mg}$ ' $\mathrm{N}$ '/g of malate in A. brasilense and minimum of $3.3 \mathrm{mg}$ nitrogen $/ \mathrm{g}$ of malate in $A$. halopreferens isolated from the soils of Thanjavur district.

\section{In vitro IAA synthesis}

The isolates were screened for IAA synthesis. IAA synthesized by Azospirillum isolates ranged from $6.50 \mu \mathrm{g} / \mathrm{ml}$ to $17.44 \mu \mathrm{g} / \mathrm{ml}$ of broth medium. Among all the isolates verified, the isolate ATR-32 synthesized significantly higher amount of IAA $(17.44 \mu \mathrm{g} / \mathrm{ml}$ of broth medium) may be the isolate was more potential and well-adjusted to the medium. Gadagi (2000) observed 1.12 to $38.12 \mu \mathrm{g} 100$ $\mathrm{ml}^{-1}$ IAA production.

Ruíz-Sáncheza et al., (2011) examined the response of rice plants to inoculation with $A$. brasilense. Result showed that A. brasilense was able to enhance ascorbate content on rice plants.

A total of forty Azospirillum isolates were isolated from root bits of Tuberose grown in Raichur and were characterized based on morphological and biochemical characteristics. 
Table.1 Biochemical characterization of Azospirillum isolates isolated from rhizosphere soil of Tuberose grown at New Herbal garden, UAS Raichur

\begin{tabular}{|c|c|c|c|c|c|c|}
\hline $\begin{array}{l}\text { Sl. } \\
\text { No. }\end{array}$ & $\begin{array}{l}\text { Isolate } \\
\text { code }\end{array}$ & $\begin{array}{c}\text { Glucose } \\
\text { utilization }\end{array}$ & $\begin{array}{c}\text { Denitrification } \\
\text { test }\end{array}$ & $\begin{array}{c}\text { Acid } \\
\text { production }\end{array}$ & $\begin{array}{c}\text { Biotin } \\
\text { requirement }\end{array}$ & Tentative identification \\
\hline 1. & ATR - 1 & + & $+\mathrm{ve}$ & ++ & - ve & Azospirillum brasilense \\
\hline 2. & ATR - 2 & ++ & - ve & ++ & - ve & Azospirillum brasilense \\
\hline 3. & ATR - 3 & +++ & - ve & + & + ve & Unidentified \\
\hline 4. & ATR - 4 & +++ & - ve & +++ & + ve & Unidentified \\
\hline 5. & ATR - 5 & + & $+\mathrm{ve}$ & ++ & - ve & Azospirillum brasilense \\
\hline 6. & ATR - 6 & +++ & - ve & ++ & + ve & Unidentified \\
\hline 7. & ATR - 7 & ++ & $+\mathrm{ve}$ & + & + ve & Unidentified \\
\hline 8. & ATR - 8 & ++ & - ve & + & - ve & Azospirillum brasilense \\
\hline 9. & ATR - 9 & ++ & + ve & ++ & - ve & Azospirillum brasilense \\
\hline 10. & ATR -10 & +++ & + ve & + & + ve & Unidentified \\
\hline 11. & ATR - 11 & +++ & + ve & +++ & - ve & Azospirillum brasilense \\
\hline 12. & ATR - 12 & ++ & - ve & ++ & - ve & Azospirillum brasilense \\
\hline 13. & ATR - 13 & + & - ve & ++ & + ve & Unidentified \\
\hline 14. & ATR - 14 & + & - ve & + & - ve & Azospirillum brasilense \\
\hline 15. & ATR - 15 & + & - ve & + & + ve & Unidentified \\
\hline 16. & ATR - 16 & ++ & - ve & +++ & - ve & Azospirillum brasilense \\
\hline 17. & ATR - 17 & ++ & - ve & ++ & $+\mathrm{ve}$ & Unidentified \\
\hline 18. & ATR - 18 & + & + ve & ++ & - ve & Azospirillum brasilense \\
\hline 19. & ATR - 19 & +++ & - ve & ++ & $+\mathrm{ve}$ & Unidentified \\
\hline 20. & ATR - 20 & ++ & + ve & ++ & - ve & Azospirillum brasilense \\
\hline 21. & ATR - 21 & ++ & + ve & ++ & + ve & Unidentified \\
\hline 22. & ATR - 22 & + & - ve & ++ & - ve & Azospirillum brasilense \\
\hline 23. & ATR - 23 & ++ & - ve & + & - ve & Azospirillum brasilense \\
\hline 24. & ATR - 24 & + & - ve & + & - ve & Azospirillum brasilense \\
\hline 25. & ATR - 25 & + & - ve & ++ & + ve & Unidentified \\
\hline 26. & ATR - 26 & ++ & $+\mathrm{ve}$ & + & - ve & Azospirillum brasilense \\
\hline 27. & ATR - 27 & + & - ve & ++ & + ve & Unidentified \\
\hline 28. & ATR - 28 & + & + ve & ++ & - ve & Azospirillum brasilense \\
\hline 29. & ATR - 29 & + & + ve & + & + ve & Unidentified \\
\hline 30. & ATR - 30 & ++ & - ve & +++ & + ve & Unidentified \\
\hline 31. & ATR - 31 & + & - ve & ++ & - ve & Azospirillum brasilense \\
\hline 32. & ATR - 32 & +++ & - ve & ++ & $+\mathrm{ve}$ & Unidentified \\
\hline 33. & ATR - 33 & ++ & + ve & ++ & - ve & Azospirillum brasilense \\
\hline 34. & ATR - 34 & + & - ve & + & + ve & Unidentified \\
\hline 35. & ATR - 35 & + & - ve & +++ & - ve & Azospirillum brasilense \\
\hline 36. & ATR - 36 & +++ & - ve & ++ & + ve & Unidentified \\
\hline 37. & ATR - 37 & ++ & + ve & + & + ve & Unidentified \\
\hline 38. & ATR - 38 & ++ & + ve & + & + ve & Unidentified \\
\hline 39. & ATR - 39 & +++ & - ve & ++ & $+\mathrm{ve}$ & Unidentified \\
\hline 40. & ATR - 40 & ++ & $+\mathrm{ve}$ & ++ & - ve & Azospirillum brasilense \\
\hline
\end{tabular}


Table.2 In vitro screening of Azospirillum isolates through Nitrogen fixation and IAA production

\begin{tabular}{|c|c|c|c|}
\hline Sl. No. & Isolate code & $\begin{array}{c}\text { IAA } \\
(\mu \mathrm{g} / \mathrm{ml} \text { of medium })\end{array}$ & $\begin{array}{c}\text { Nitrogen fixed }(\mathrm{mg} / \mathrm{g} \text { of } \\
\text { malate) }\end{array}$ \\
\hline 1. & Control & 0.00 & 0.06 \\
\hline 2. & ATR-2 & 11.60 & 14.0 \\
\hline 3. & ATR-3 & 8.36 & 12.8 \\
\hline 4. & ATR-4 & 13.40 & 13.1 \\
\hline 5. & ATR-6 & 14.18 & 16.6 \\
\hline 6. & ATR-8 & 13.08 & 14.2 \\
\hline 7. & ATR-12 & 10.30 & 12.8 \\
\hline 8. & ATR-13 & 9.60 & 13.9 \\
\hline 9. & ATR-14 & 9.70 & 14.0 \\
\hline 10. & ATR-15 & 6.50 & 13.3 \\
\hline 11. & ATR-16 & 11.76 & 12.7 \\
\hline 12. & ATR-17 & 12.60 & 13.0 \\
\hline 13. & ATR-19 & 14.06 & 15.8 \\
\hline 14. & ATR-22 & 10.30 & 13.4 \\
\hline 15. & ATR-23 & 12.04 & 13.4 \\
\hline 16. & ATR-24 & 8.48 & 13.7 \\
\hline 17. & ATR-25 & 11.70 & 14.5 \\
\hline 18. & ATR-27 & 7.80 & 14.2 \\
\hline 19. & ATR-30 & 10.84 & 13.7 \\
\hline 20. & ATR-31 & 14.02 & 14.0 \\
\hline 21. & ATR-32 & 17.44 & 16.2 \\
\hline 22. & ATR-34 & 11.44 & 15.1 \\
\hline 23. & ATR-35 & 13.42 & 12.7 \\
\hline 24. & ATR-36 & 16.64 & 15.4 \\
\hline 25. & ATR-39 & 14.88 & 15.3 \\
\hline 26. & $\begin{array}{l}\text { Reference strain } \\
\quad(\text { ACD-15) }\end{array}$ & 13.99 & 14.3 \\
\hline
\end{tabular}


Twenty four isolates were negative for denitrification test and these isolates were used for further screening (Isolates which are positive for denitrification were not used for further studies, as denitrification is a harmful process for agriculture with the loss of available nitrogen). The isolate ATR-6 was found to fix significantly higher nitrogen under in vitro conditions. All the isolates could produce IAA but significantly highest IAA was synthesized by isolate ATR-32. Isolates viz., ATR-06 and ATR-32 shall be used as bio-inoculants for bio fertilizer production.

\section{Acknowledgement}

Authors are thankful to the, Department of Agricultural Microbiology, University of Agriculture sciences, Raichur for providing the necessary facilities in accomplishing the research work.

\section{References}

Bashan, Y. and Holguin, G., 1994, Root to root travel of the beneficial bacterium Azospirillum brasilense. Appl. Environ. Microbiol, 60: 2120-2131.

Bashan, Y., Levanony, H. and Ziv-Vecht, O., 1987, The fate of field inoculated Azospirillum brasilense in wheat rhizosphere during the growing season. Can. J. Microbiol., 35: 691-697.

Coninck, D. K., Horemans, S., Randombage, S. and Vlassak, K., 1988, Occurrence and survival of Azospirillum spp. in temperate regions. Plant Soil, 110: 213.

Dobereiner, J. and Day, J. M., 1976, First international symposium on nitrogen fixation. In: Proceedings of International Symposium on Nitrogen Fixation, Ed. Newton, W.E. and Nyman, C.J., Washington State University Press, Pullman, W.A., pp. 518-538.
Gadagi, R., 2000, Studies on Azospirillum isolates of ornamental plants and their effect on Gaillardia pulchella var. Picta fouger. Ph. D. Thesis, Univ. Agric. Sci., Dharwad.

Haathella, K., Kari, K. and Sundman, V., 1983, Nitrogenase activity (acetylene reduction) of root associated, cold climate Azospirillum, Enterobacter, Klebsiella and Pseudomonas species during growth on various carbon sources and varies partial pressures of oxygen. Appl. Environ. Microbiol., 45: 563-571.

James, E., 2000, Nitrogen fixation in endophytic and associative symbiosis. Field Crops Res., 65: 197-209.

Kanimozhi, K. and Panneerselvam, A., 2010, Studies on isolation and nitrogen fixation ability of Azospirillum spp. isolated from Thanjavur district, Der Chemica Sinica, 1(3): 138-145.

Michiels, K., Vanderleyden, J. and Vangool, A., 1989, Azospirillum-plant root associations. Biol. Fertil. Soil, 8: 356368.

Okon, Y. and Itzigsohn, R., 1995, The development of Azospirillum as a commercial inoculants for improving crop yields. Biotechnol. Adv., 13: 365374.

Okon, Y., Albrecht, S. L. and Burris, R. H., 1977, Methods for growing Spirillum lipoferum and for counting it in pure culture and in association with plants. Appl. Environ. Microbiol, 33: 83-85.

Reynders, L and Vlassak, K. 1979, Conversion of tryptophan to indoleacetic acid by Azospirillum brasilense. Soil Biol. Biochem. 11: 547548.

Ruiz-Sancheza, M., Armadab, E., Mũnoza, Y., Inés, E., García de Salamonec., Arocab, R., Ruíz-Lozanob, J. M. and Azcón, R., 2011, Azospirillum and arbuscular mycorrhizal colonization 
enhance rice growth and physiological traits under well-watered and drought conditions, J. Plant Physiol., 168: 10311037.

Savalgi, V. P., Onkarappa, R., Veena Savalgi, and Gurumurthy S. B., 2009, Screening of plant grown promotional activities and diazotrophic activities of Azospirillum strains from vertisols of Northern Karnataka. Karnataka J. Agric. Sci., 22(5).
Veena, S. C., 1999, Development of inoculum consortia for enhanced growth and nutrient uptake by sorghum. M.Sc. (Agri.) Thesis, Univ. of Agric. Sci., Dharwad.

Wani, S. P., 1990, Inoculation with associative nitrogen fixing bacteria: Role in cereal grain production improvement. Indian J. Microbiol., 30: 363-393.

\section{How to cite this article:}

Avinash, M. and Mahadeva Swamy. 2018. Isolation, Characterization and Screening of Azospirillum from Tuberose Rhizoplane in Raichur. Int.J.Curr.Microbiol.App.Sci. 7(11): 774780. doi: https://doi.org/10.20546/ijcmas.2018.711.093 